\title{
THE EFFECT OF FATAL $P$. KNOWLESI MALARIA ON SIMIAN CIRCULATORY AND BODY FLUID COMPARTMENT PHYSIOLOGY ${ }^{1}$
}

\author{
BY RICHARD R. OVERMAN AND HARRY A. FELDMAN 2 \\ (From the Departments of Physiology and Preventive Medicine, University of Teniessce, \\ College of Medicine, Memphis)
}

(Received for publication October 30, 1946)

Although some objective measurements of the altered physiology of the malarial host have been made in human patients with therapeutic $P$. vivax and $P$. falciparum infections (1), almost no such studies have been made of the circulatory and fluid compartment volumes in fatal malaria. Numerous conclusions regarding the altered fluid physiology of the monkey with fatal $P$. knowlesi infections have been. made by Knisely, et al (2), but these were, essentially, inferences based on microscopic observations of the capillaries (omentum, stomach, intestine and peritoneum) of living animals. The present investigation was made to elicit objective information concerning the altered physiological mechanisms in monkeys fatally ill of malaria.

\section{MATERIALS AND METHODS}

The following control determinations were made in 23 normal Macacus mulata monkeys who varied in weight from 2.45 to $4.40 \mathrm{kgm}$.: (a) total plasma volume by a modification (3) of the T-1824 dye dilution method of Gibson and Evans (4), (b) NaSCN ("extracellular") volume by a modification (3) of the method of Crandall and Anderson (5), (c) plasma protein concentration by the $\mathrm{CuSO}_{4}$ method of Phillips, Van Slyke, et al (6), (d) arterial and venous blood oxygen content by the microgasometric procedure of Roughton and Scholander (7), (e) circulation times by a modification (3) of the fluorescein method of Fishback, et al (8), and $(f)$ venous hematocrit values using Wintrobe tubes and centrifuging the heparinized blood for $1 / 2$ hour at 3,000 r.p.m.

The total blood volume (TBV) was calculated from the measured plasma volume and average venous hematocrit value. The circulating red cell mass (TRBC) was calculated by subtracting the plasma volume from the total blood volume. The total circulating protein (TCPr.) was derived from the plasma protein concentration and the plasma volume. Each fluid volume measurement was

1 The work described in this paper was done under a contract recommended by the Committee on Medical Research, between the Office of Scientific Research and Development and the University of Tennessee.

2 Lieutenant-Colonel, M.C., AUS. related to the body weight of the animal at the time of the determination.

Immediately following the control determinations, 16 of the animals were infected with $P$. knozvlesi by intravenous injection of small amounts $(0.25$ to $2.00 \mathrm{ml}$.) of whole blood from other animals with acute infections. The survival period of these experimental animals was 4 to 12 days with an average of 7.1 days. A total of 32 sets of the above determinations were carried out on the 16 animals, beginning on the second day post-inoculation and extending up to within $1 / 2$ hour of death. Determinations of the level of parasitemia were made at least daily on each animal.

Following the withdrawal of the last dye- $\mathrm{NaSCN}$ sample, $1 \mathrm{ml}$. of femoral arterial and $1 \mathrm{ml}$. of femoral venous blood were airlessly withdrawn as near simultaneously as possible (within 2 minutes) and the oxygen content immediately determined by the Roughton-Scholander method. Immediate measurement of the $\mathrm{O}_{2}$ content is imperative in the blood of the malarious animal (especially those at high parasitemic levels) because the parasites use oxygen at a rapid rate. Allowing the samples to stand, even using the precaution of storage at low temperatures as described by Roughton (7) for normal blood, will lead to gross errors in the true $\mathrm{O}_{2}$ content of paludic blood.

At the end of each set of determinations, i.e., after the $\mathrm{O}_{2}$ content of arterial and venous blood and the circulation time had been measured, the femoral triangle was closed by 3 or 4 skin clips and the animal returned to the cage. Since no sterile precautions were observed on exposing the artery and vein, some of the animals were given 10,000 units of penicillin intramuscularly to minimize local infection. However, such precaution was not always taken and the few skin-clip infections which developed were treated as soon as they were discovered. The right and left femoral triangles were alternated for serial studies. Local anesthesia was employed by infiltration of the femoral triangle region with $2 \mathrm{ml}$. of 2 per cent procaine.

More pronounced alterations in fluid and circulatory physiology were anticipated as the parasitemic level rose. Multiple measurements at each parasitemic level were desirable, but not always feasible. Consequently, the results have been analyzed by grouping the data in a logical but arbitrary manner. It was noted that if less than 10 per cent of the red cells of the monkey were parasitized, the animal, while showing definite clinical signs (increased body temperature, reduced hematocrit, increased "extra- 
cellular" fluid volume), is not acutely ill. At such levels the fatal course may be readily averted by adequate chemotherapy. Likewise, such animals are alert and active; peripheral blood can be readily drawn; and the monkey has the outward appearance of a normal animal.

However, with parasite levels at which more than 10 per cent of the red cells are parasitized, the fatal course is not easily reversed by chemotherapeutic intervention; the animals may be myasthenic and often appear depressed; it becomes increasingly difficult to draw blood from the peripheral veins or, at times, ever to obtain capillary blood for smears. These conditions continue and become progressively more pronounced until death. Thus, we have divided the determinations made in this series into 4 groups: (1) normal (control) values, (2) values obtained on animals having less than 10 per cent parasitemia, (3) values obtained on animals having greater than 10 per cent parasitemia, and (4) values obtained within the 24-hour period preceding death.

\section{RESULTS}

In general the data are presented and discussed by comparing the averages of the 4 groups ( $\mathrm{Ta}$ bles I, II). Entirely similar results were obtained by calculating the changes in individual animals.

Plasma volume. Figure 1 shows the changes in plasma volume expressed as $\mathrm{ml}$. per $\mathrm{kgm}$. of body weight. It will be seen that the plasma volume increases throughout the course of the disease until just before death. Red cell destruction is a constant feature of active malaria; and, therefore, an increase in plasma volume is not unexpected, since the usual physiological mechanism for maintaining a constant blood volume in the presence of erythrocyte loss is plasma dilution. The terminal fall in plasma volume may reflect either (1) pooling of blood in regions which the dye cannot penetrate except by diffusion or (2) increased capillary leakage. However, none of the plasma volume alterations reveal statistical significance (Table II).

Blood volume. Although the plasma volume shows progressive enlargement until just before death from malaria, the whole blood volume is reduced early in the disease. It is obvious that

TABLE I

Comparison of average values in groups 1,2, 3 and $4^{*}$

\begin{tabular}{|c|c|c|c|c|c|c|c|c|c|c|c|c|c|}
\hline Group & Hct. ${ }^{\dagger}$ & TPV & $\underset{\text { per kgm. }}{\text { PV }}$ & TBV & $\begin{array}{c}\text { BV } \\
\text { per kgm. }\end{array}$ & TEFV & $\begin{array}{c}\text { EFV } \\
\text { per kgm. }\end{array}$ & TRBC & $\begin{array}{c}\mathrm{RBC} \\
\text { per } \mathrm{kgm} .\end{array}$ & Pl. Pr. & TCPr. & $\mathrm{A}-\mathrm{V} \mathrm{O}_{2}$ & C. T. \\
\hline $\begin{array}{l}1 \\
\text { s.d. } \\
\text { s.e. }\end{array}$ & $\begin{array}{r}40.4 \\
5.2 \\
1.1\end{array}$ & $\begin{array}{r}163.3 \\
52.9 \\
11.3\end{array}$ & $\begin{array}{r}44.9 \\
8.9 \\
1.9\end{array}$ & $\begin{array}{r}273.1 \\
83.5 \\
17.8\end{array}$ & $\begin{array}{r}75.1 \\
13.4 \\
2.9\end{array}$ & $\begin{array}{r}725.8 \\
169.5 \\
43.8\end{array}$ & $\begin{array}{r}208.9 \\
43.4 \\
11.2\end{array}$ & $\begin{array}{r}110.2 \\
39.2 \\
2.7\end{array}$ & $\begin{array}{r}29.9 \\
6.4 \\
1.4\end{array}$ & $\begin{array}{l}6.97 \\
0.72 \\
0.17\end{array}$ & $\begin{array}{r}11.3 \\
4.2 \\
0.3\end{array}$ & $\begin{array}{l}6.9 \\
2.2 \\
0.4\end{array}$ & $\begin{array}{l}9.5 \\
2.2 \\
0.7\end{array}$ \\
\hline $\begin{array}{l}2 \\
\text { s.d. } \\
\text { s.e. }\end{array}$ & $\begin{array}{r}31.1 \\
8.1 \\
2.0\end{array}$ & $\begin{array}{r}158.8 \\
32.9 \\
8.2\end{array}$ & $\begin{array}{r}46.4 \\
8.4 \\
2.1\end{array}$ & $\begin{array}{r}231.5 \\
47.6 \\
11.9\end{array}$ & $\begin{array}{r}67.9 \\
12.4 \\
3.1\end{array}$ & $\begin{array}{r}1046.0 \\
473.6 \\
131.2\end{array}$ & $\begin{array}{r}322.4 \\
130.7 \\
36.3\end{array}$ & $\begin{array}{r}72.7 \\
27.1 \\
6.8\end{array}$ & $\begin{array}{r}21.3 \\
8.3 \\
2.1\end{array}$ & $\begin{array}{l}6.94 \\
0.64 \\
0.17\end{array}$ & $\begin{array}{r}10.6 \\
2.1 \\
0.6\end{array}$ & $\begin{array}{l}6.4 \\
2.5 \\
0.9\end{array}$ & $\begin{array}{l}9.3 \\
2.4 \\
0.7\end{array}$ \\
\hline $\begin{array}{l}3 \\
\text { s.d. } \\
\text { s.e. }\end{array}$ & $\begin{array}{r}24.2 \\
6.7 \\
2.6\end{array}$ & $\begin{array}{r}185.2 \\
26.0 \\
9.8\end{array}$ & $\begin{array}{r}51.6 \\
6.4 \\
2.4\end{array}$ & $\begin{array}{r}246.2 \\
41.1 \\
15.6\end{array}$ & $\begin{array}{r}68.1 \\
7.0 \\
2.7\end{array}$ & $\begin{array}{r}1071.9 \\
398.9 \\
178.4\end{array}$ & $\begin{array}{r}314.1 \\
111.5 \\
49.9\end{array}$ & $\begin{array}{r}61.1 \\
23.6 \\
8.9\end{array}$ & $\begin{array}{r}16.5 \\
5.0 \\
1.9\end{array}$ & $\begin{array}{l}6.80 \\
0.74 \\
0.32\end{array}$ & $\begin{array}{r}12.7 \\
1.4 \\
0.6\end{array}$ & $\begin{array}{l}6.2 \\
2.1 \\
1.5\end{array}$ & $\begin{array}{l}9.0 \\
2.9 \\
2.0\end{array}$ \\
\hline $\begin{array}{l}4 \\
\text { s.d. } \\
\text { s.e. }\end{array}$ & $\begin{array}{r}22.4 \\
10.6 \\
4.3\end{array}$ & $\begin{array}{r}133.6 \\
43.2 \\
19.3\end{array}$ & $\begin{array}{r}38.0 \\
12.7 \\
5.7\end{array}$ & $\begin{array}{r}157.2 \\
40.4 \\
18.1\end{array}$ & $\begin{array}{r}48.5 \\
11.3 \\
5.1\end{array}$ & $\begin{array}{r}1077.9 \\
357.0 \\
145.7\end{array}$ & $\begin{array}{r}344.8 \\
82.8 \\
33.8\end{array}$ & $\begin{array}{r}33.6 \\
10.4 \\
4.7\end{array}$ & $\begin{array}{l}7.8 \\
3.7 \\
1.7\end{array}$ & $\begin{array}{l}6.44 \\
0.36 \\
0.41\end{array}$ & $\begin{array}{l}7.9 \\
2.5 \\
1.1\end{array}$ & $\begin{array}{l}7.7 \\
2.3 \\
1.3\end{array}$ & $\begin{array}{r}19.5 \\
10.5 \\
5.2\end{array}$ \\
\hline
\end{tabular}

* Group 1-normal values (23 monkeys).

Group 2-animals with less than 10 per cent parasitemia (17 animals).

Group 3-animals with greater than 10 per cent parasitemia at least 30 hours before death (8 animals).

Group 4 -animals measured on the day of death (all had greater than 10 per cent parasitemia) (7 animals).

$\dagger$ Hct. - hematocrit in per cent.

TPV - total plasma volume in $\mathrm{ml}$.

$\mathrm{PV}$ per kgm.- plasma volume in $\mathrm{ml}$. per $\mathrm{kgm}$.

TBV - total blood volume in $\mathrm{ml}$.

$\mathrm{BV}$ per $\mathrm{kgm}$. - blood volume in $\mathrm{ml}$. per $\mathrm{kgm}$.

TEFV - "extracellular" fluid volume in $\mathrm{ml}$.

EFV per kgm.- "extracellular" fluid volume in $\mathrm{ml}$. per $\mathrm{kgm}$.

TRBC - total erythrocyte mass in $\mathrm{ml}$.

RBC per kgm. - erythrocyte mass in $\mathrm{ml}$. per $\mathrm{kgm}$.

Pl. Pr. - plasma protein concentration in grams per cent.

TCPr. - total circulating protein in grams.

$\mathrm{A}-\mathrm{V} \mathrm{O}_{2}$-arterio-venous oxygen difference in volumes per cent.

C. T. - circulation time (femoral vein to tongue) in seconds. 
TABLE II

Statistical comparison ( $T$ values) of circulatory and fluid compartment physiology in groups $1,2,3$, and $4 \dagger$

\begin{tabular}{|c|c|c|c|c|c|c|c|c|c|c|c|c|c|}
\hline $\begin{array}{l}\text { Between } \\
\text { groups }\end{array}$ & Hct. & TPV & $\underset{\text { per } \mathbf{~ k g m} .}{\text { PV }}$ & TBV & $\underset{\text { per kgm. }}{\text { BV }}$ & TEFV & $\begin{array}{c}\text { EFV } \\
\text { per kgm. }\end{array}$ & TRBC & $\begin{array}{c}\mathrm{RBC} \\
\text { per } \mathrm{kgm} .\end{array}$ & Pl. Pr. & TCPr. & $\mathrm{A}-\mathrm{V} \mathrm{O}_{2}$ & C. T. \\
\hline $\begin{array}{l}1 \text { and } 2 \\
1 \text { and } 3 \\
1 \text { and } 4 \\
3 \text { and } 4\end{array}$ & $\begin{array}{l}4.04^{*} \\
5.85^{*} \\
3.96^{*} \\
0.36\end{array}$ & $\begin{array}{l}0.32 \\
1.46 \\
1.33 \\
2.68\end{array}$ & $\begin{array}{l}0.57 \\
2.18 \\
1.16 \\
2.21\end{array}$ & $\begin{array}{l}1.94 \\
1.14 \\
4.57^{*} \\
3.73^{*}\end{array}$ & $\begin{array}{l}1.71 \\
1.80 \\
4.59^{*} \\
3.43^{*}\end{array}$ & $\begin{array}{l}2.31 \\
1.88 \\
2.31 \\
0.03\end{array}$ & $\begin{array}{l}2.99^{*} \\
2.06 \\
2.82^{*} \\
0.51\end{array}$ & $\begin{array}{r}5.16^{*} \\
5.29^{*} \\
14.29^{*} \\
2.75^{*}\end{array}$ & $\begin{array}{r}3.28^{*} \\
5.73^{*} \\
10.18^{*} \\
3.44^{*}\end{array}$ & $\begin{array}{l}0.01 \\
0.47 \\
2.36 \\
1.04\end{array}$ & $\begin{array}{l}0.06 \\
1.25 \\
2.28 \\
3.75^{*}\end{array}$ & $\begin{array}{l}0.45 \\
0.47 \\
0.54 \\
0.74\end{array}$ & $\begin{array}{l}0.20 \\
0.24 \\
1.89 \\
1.87\end{array}$ \\
\hline
\end{tabular}

* These values are significant at the 1 per cent level.

† Footnotes in Table I applicable also to Table II.

this reduction is entirely due to red cell destruction which begins with, or shortly after, inoculation. However, the reduction in whole blood volume is not, in itself, serious until the terminal stages are reached when the average reduction is 42.4 per cent. It is highly probable that such a loss may lead to circulatory failure and a fatal outcome.

Erthrocyte mass. The loss in circulating red cell volume throughout the course of fatal $P$. knowlesi infections is almost linear (Figure 1). The average terminal reduction reached the high figure of 73.9 per cent at which time the average red cell mass per $\mathrm{kgm}$. was but $7.8 \mathrm{ml}$. Neither the whole blood volume nor the hematocrit (Figure 1, Table I) shows parallel alterations due to the fact that the plasma volume increases in early malaria and does not fall as precipitously as does the red cell volume in the terminal stages.
Plasma protein. While the plasma protein concentration shows a small but progressive reduction during the course of the disease (Figure 2 , Table I), the total circulating protein increases until just before death. The explanation for these results lies in the observed fact that there is a gradual increase in plasma volume until the day of death. The terminal fall in total circulating protein (which is statistically significant [Table II]) indicates again that increased capillary leakage may occur near the end of the fatal course. Arterio-venous oxygen difference. The difference between the $\mathrm{O}_{2}$ content of arterial and venous blood reveals minor changes during early malaria (Figure 2, Table I) with a marked terminal rise. Due to the drastically reduced blood volume and prolonged circulation time at this stage, the volume flow throughout any portion of the capillary bed must be materially reduced terminally.

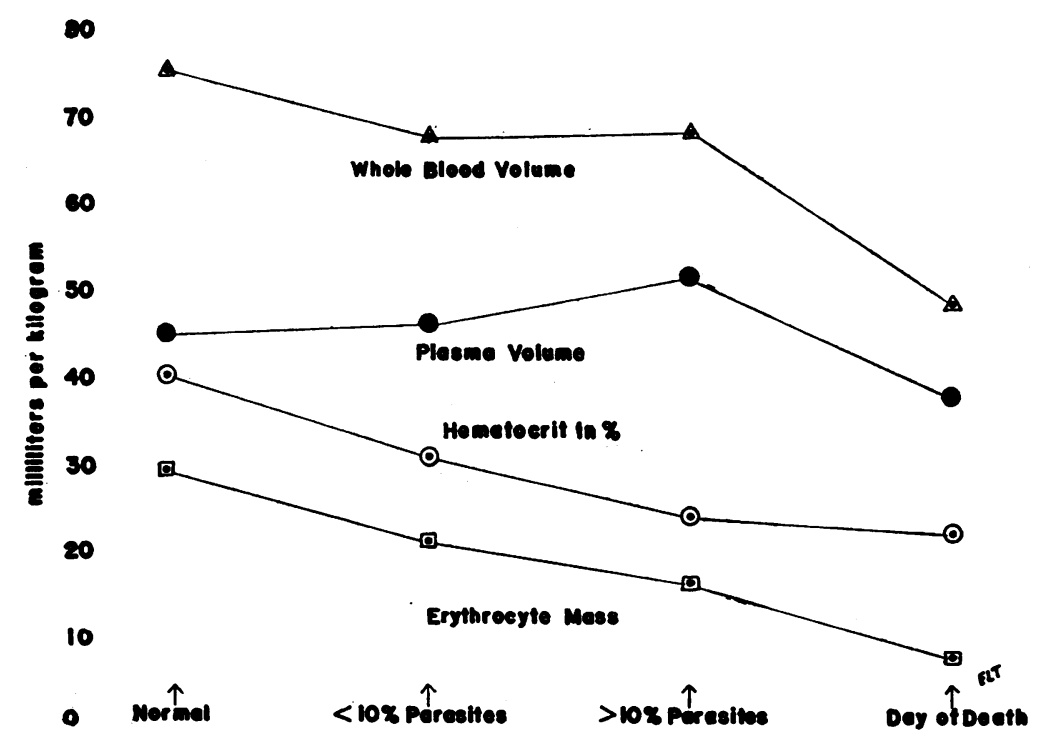

Fig. 1. Changes in Blood and Plasma Volumes in Fatal Simian Malaria 


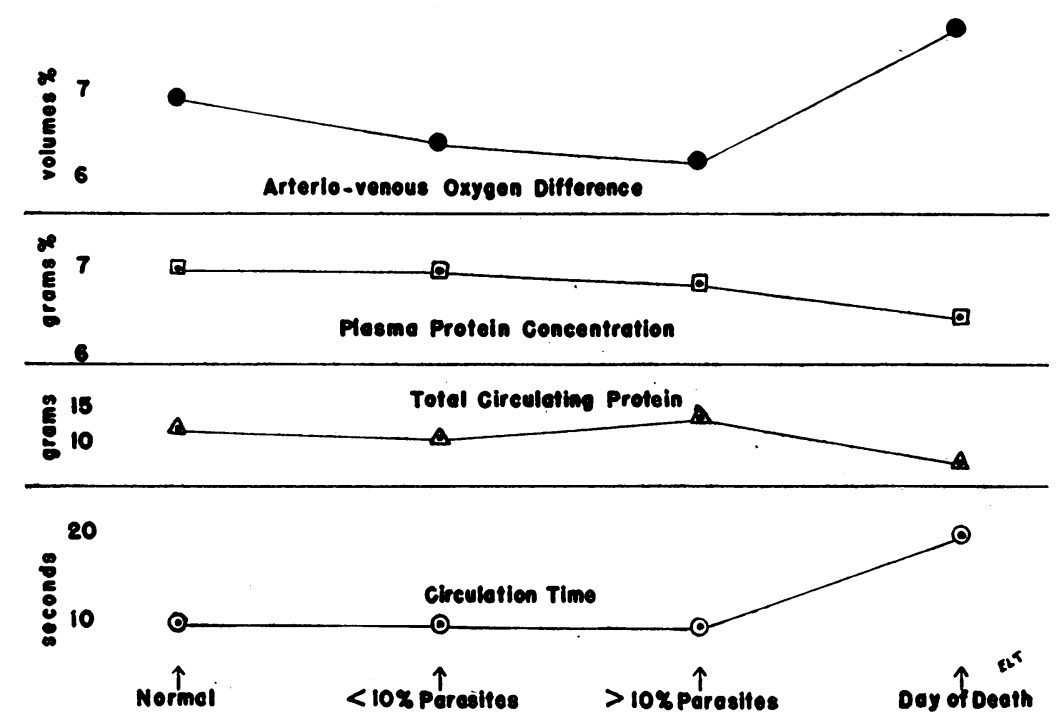

Fig. 2. Average Physiological Alterations in Fatal Simian Malaria

Therefore, such an increase in $\mathrm{A}-\mathrm{V}$ difference at this time is not unexpected.

Circulation time. During the early stages of malaria, the circulation time shows minor reductions (Figure 2, Table I). That this is a concomitant of dilution of the blood (loss of red cells and increase of plasma) and a lowered viscosity is highly probable. Terminally there may be a doubling of the circulation time. Our results indicate that although such a terminal slowing of the circulation could be due to intravascular agglutination which apparently occurs at this time (2), it could likewise be ascribed to vasoconstriction which occurs to compensate for the reduced circulatory volume.

"Extracellular" fluid volume. The volume of fluid which is available for the dilution of $\mathrm{NaSCN}$ ("extracellular") increases in a progressive manner throughout the fatal course of $P$. knowlesi infections in the monkey. Actually, the grouped data (Figure 3, Table I) mask some of the more startling alterations of this volume in some of the animals. Usually the apparent "extracellular" volume exceeded 60 per cent of the body weight

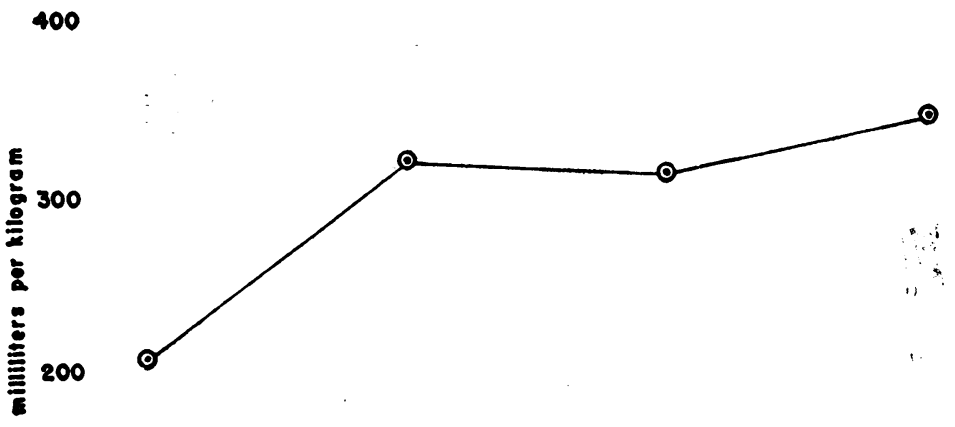

100

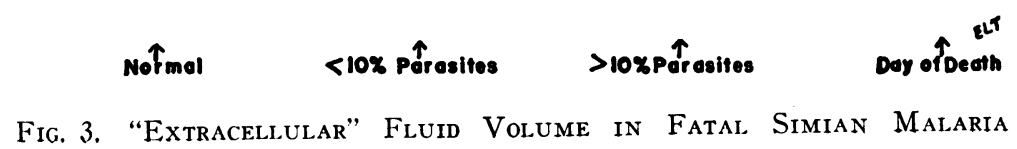


just preceding death of animals whose survival period and consequently the febrile period was prolonged (10 to 12 days).

\section{DISCUSSION}

Feldman and Murphy (1), who measured the blood and plasma volumes in sporozoite-induced malaria in the human being, pointed out that "the plasma volume is increased almost without exception during the active phase of vivax and falciparum infections studied." On the other hand, Knisely, et al (2) inferred from microscopic observations of the capillaries of living monkeys infected with knowlesi that "there is a progressively decreased circulating plasma volume."

From the measurements reported here; it is now possible to resolve these 2 divergent views. In early malaria (in fact, up until the day of death in simian malaria), the plasma volume is progressively increased. The patients studied by Feldman and Murphy, while seriously infected, were not usually in the final stages of the disease. Indeed, there were noted in 1 patient (described as being in shock) plasma and blood volume reductions of 46 and 57 per cent, respectively. This patient recovered following transfusion with whole blood and plasma. Knisely, et al, on the other hand, were observing the alterations in the monkey infected with an almost uniformly fatal type of malaria, and their conclusions were based primarily on observations made near the time of death.

As was observed in the human being (1), the monkey shows a marked and progressive fall in the venous hematocrit value. These observations do not support the subjective inference of Knisely that at times "the venous blood shows high red cell counts (hemoconcentration)."

Since the early reduction in circulating blood volume is due entirely to red cell destruction, it follows that the oxygen-carrying capacity of the blood will be reduced by at least a similar percentage. Indeed, since the presence of the parasite within the red cell reduces its ability to carry oxygen (by destroying hemoglobin) (9), one would expect an even greater decrease in the $\mathrm{O}_{2}$ capacity of the arterial blood than the anemia would indicate.
The severe reduction in the number of circulating red cells and in the ability of some of the circulating cells to carry oxygen is associated, at least terminally, with a 100 per cent increase (prolongation) of the circulation time. That tissue anoxia will result is an obvious corollary of these findings.

At the outset, the progressive apparent increase in the size of the "extracellular" compartment in simian malaria was difficult to explain. As previously mentioned, animals having the longest periods of survival (10 to 12 days) revealed apparent "extracellular" volumes which exceeded 60 per cent of the body weight. Since the plasma volume and the body weight fall terminally, it is evident that in the malarious monkey $\mathrm{NaSCN}$ no longer measures the "extracellular" water. One of the present authors (10) has shown that in febrile conditions $\mathrm{SCN}$ enters the tissue cells and becomes diluted by the entire water mass of the body.

Since the tissue cell, at elevated body temperatures, becomes permeable to the $\mathrm{SCN}$ ion which it normally excludes, it follows that cellular permeability to native ions might also be altered under the same or similar conditions. Pinelli (11), Velick and Scudder (12), Zwemer, Sims and Coggeshall (13), Flosi (14), and Morin, Bader, Monnier and Moreau (15) have all reported a decrease in blood sodium or chloride and/or an increase in blood potassium concentration in malaria.

Our observations indicate that such changes may occur as a result of altered cellular permeability in febrile states. That the entrance of $\mathrm{Na}$ and $\mathrm{Cl}$ into cells and the loss of $\mathrm{K}$ from cells might be accompanied by severe metabolic disturbances leading to a fatal outcome cannot be overlooked.

\section{SUMMARY AND CONCLUSIONS}

1. Repeated measurements of plasma, blood and "extracellular" fluid volumes, hematocrit values, plasma protein concentration, arteriovenous oxygen differences, and circulation time have been made in 16 Macacus mulata monkeys with fatal $P$. knozelesi infections.

2. Statistically significant alterations in some of these values appear early in the disease and 
become progressively more intense throughout the fatal course.

3. The severity of the measured changes indicates that death in simian malaria may result from (a) circulatory failure, (b) anoxia, and (c) altered cellular permeability. It is suggested that such findings are applicable to malarial infections in man.

\section{ACKNOWLEDGMENT}

The technical assistance of Mr. Robert Henderson and Mr. Chris Demos, medical students at the University of Tennessee College of Medicine, and Miss Elva Tharp in the course of this investigation is gratefully acknowledged. The authors are also indebted to Miss Virginia $\mathrm{H}$. Fogg and Miss Salley T. Haynes of the Malaria Investigations Laboratory, Department of Health and Safety, Tennessee Valley Authority, for making the parasite counts in this study.

\section{BIBLIOGRAPHY}

1. Feldman, Harry A., and Murphy, Franklin D., The effect of alterations in blood volume on the anemia and hypoproteinemia of human malaria. J. Clin. Invest., 1945, 24, 780.

2. Knisely, Melvin H., Stratman-Thomas, Warren K., Eliot, Theodore S., and Bloch, Edward H., Knowlesi malaria in monkeys. I. Microscopic pathological circulatory physiology of rhesus monkeys during acute Plasmodium knozelesi malaria. J. Nat. Malaria Society, 1945, 4, 285.

3. Overman, Richard R., and Feldman, Harry A., Circulatory and fluid compartment physiology in the normal monkey with especial reference to seasonal variations. Am. J. Physiol., 1947, 148, 455.

4. Gibson, J. G., 2nd, and Evans, W. A., Jr., Clinical studies of the blood volume. I. Clinical application of a method employing the azo dye "Evans blue" and the spectrophotometer. J. Clin. Invest., 1937, $16,301$.

5. Crandall, L. A., Jr., and Anderson, M. X., Estimation of the state of hydration of the body by the amount of water available for the solution of sodium thiocyanate. Am. J. Digest. Dis. \& Nutrition, 1934, $1,126$.

6. Phillips, R. A., Van Slyke, D. D., Emerson, Kendall, Jr., Hamilton, P. B., and Archibald, R. M., Copper sulfate method for measuring specific gravities of whole blood and plasma. Bull. U. S. Army M. Dept., 1943, No. 71, 66.

7. Roughton, F. J. W., and Scholander, P. F., Microgasometric estimation of the blood gases. I. Oxygen. J. Biol. Chem., 1943, 148, 541.

8. Fishback, David B., Guttman, Samuel A., and Abramson, Edwin B., An objective method of determining blood velocity (fluorescein method). Am. J. Med. Sci., 1942, 203, 535.

9. Morrison, D. B., and Anderson, W. A. D., The pigment of the malaria parasite. Pub. Health Rep., $1942,57,90$.

10. Overman, Richard R., Permeability alterations in disease. J. Lab. and Clin. Med., 1946, 31, 1170.

11. Pinelli, L., La potassiemia nella malaria. Rev. de Malariol., 1929, 3, 310.

12. Velick, S. F., and Scudder, J., Plasma potassium level in avian malaria. Am. J. Hyg., 1940, 31, 92.

13. Zwemer, R. L., Sims, E. A. H., and Coggeshall, L. T., The plasma potassium level during malaria infection in monkeys and man. Amer. J. Trop. Med., 1940, $20,687$.

14. Flosi, A. Z., Contribuicao ao estudo do natremia e da kalemia na malaria artificialmente induzida. Rev. Clin. de Sao Paulo, 1944, 16, 1.

15. Morin, M., Bader, H., Monnier, E., and Moreau, P., Sur l'hyperchlorémie globulaire des paludéens au Tonkin. Bull. Soc. Path. Exot., 1934, 27, 136. 